\title{
Analisa Tarif Jasa Layanan Sampah Dalam Upaya Peningkatan Pengelolaan Persampahan di Kecamatan Ujungberung
}

\author{
Aqilla Nabil Mukharam $^{{ }^{*}}$, Kancitra Pharmawati $^{2}$ \\ ${ }^{1,2}$ Teknik Lingkungan, Fakultas Teknik Sipil dan Perencanaan, Institut Teknologi Nasional Bandung \\ Jl. PKHH. Mustofa No.23 Bandung, 40124, Indonesia \\ *Koresponden email: mukharamaqilla@ gmail.com
}

Diterima : 4 Januari 2021

Disetujui: 4 Maret 2021

\begin{abstract}
Unfulfillment of waste service ratetarget, low-quality of waste temporary shelter, and the basic needs to increase waste service rates become the foundation to analyze the financial aspect. This can be conductedby calculating and analyzing public's Willingness to Pay (WTP) to waste management service improvements in Ujungberung Sub-District. The objectives of this research are to know the percentage of people's WTP towards the rise of waste service rates and analyze factors that can affect the WTP. The chosen method for this research is Contingent Valuation Method (CVM) with Payment Card as its technique. By using Cross-Section method, there are 66 people selected to be the samples of this study. Online questionnaire is used to collect the data. The percentage of public's WTP is $88 \%$ with the value of average WTP is Rp 31.288 and the value of total WTP is RP 113.575.000. Based on the multiple linear regression analysis, the factors significantly affecting the value of WTP are age and existing waste service rates.
\end{abstract}

Keywords: CVM, ujungberung sub-district, waste management service improvements, waste service rates, WTP

\begin{abstract}
Abstrak
Kualitas Tempat Pembuangan Sementara (TPS) belum memadai menjadi dasar perlunya analisa dan perhitungan Willingness to Pay (WTP) masyarakat Kecamatan Ujungberung terhadap peningkatan pelayanan pengelolaan persampahan. Selain itu, disebabkan pula oleh tidak terpenuhinya penerimaan iuran tarif jasa layanan (TJL) sampah dan perlunya landasan dalam membuat kebijakan kenaikan TJL. Tujuan penelitian ini adalah mengetahui persentase WTP masyarakat terhadap kenaikan TJL sampah dan menganalisa faktor-faktor yang mempengaruhi WTP nya. Metode yang digunakan adalah Contingent Valuation Method dengan teknik Payment Card. Jumlah responden yang dijadikan sampel adalah 66 jiwa dengan menggunakan cara Cross-Section. Pengumpulan data menggunakan kuesioner yang dilakukan secara dalam jaringan. Persentase WTP masyarakat akan kenaikan TJL sampah adalah $88 \%$ dengan besaran rata-rata WTP sebesar Rp 31.288 dan besaran WTP totalnya sebesar Rp 113.575.000. Berdasarkan hasil analisa regresi linear berganda, faktor yang mempengaruhi WTP secara signifikan adalah usia dan tarif jasa layanan sampah yang dibayarakan oleh masyarakat.
\end{abstract}

Kata Kunci: $C V M$, kecamatan ujungberung, peningkatan kualitas pelayanan pengelolaan persampahan, TJL, WTP

\section{Pendahuluan}

Keberhasilan pembangunan kota tidak dapat terlepas dari sistem pengelolaan sampah yang dilakukan. Dasar sistem pengelolaan sampah suatu kawasan adalah tata cara teknik operasional pengelolaan sampah di perkotaan [1][2], serta standar pengelolaan sampah [3]. Sehubungan dengan hal tersebut maka perlu dilakukan kajian terhadap seluruh aspek yang terkait dalam sistem pengelolaan persampahan. Terdapat 5 (lima) aspek utama dalam pengelolaan persampahan, yaitu 1) Teknik operasional, 2) Kelembagaan, 3) Pembiayaan, 4) Peraturan, dan 5) Peran serta masyarakat [4].

Pada Peraturan Presiden No. 97 Tahun 2017, target pengurangan sampah di Indonesia yang lalu diterapkan di setiap daerah adalah 30\% dari timbulan sampah, sedangkan target penanganan sampahnya adalah 70\% dari timbulan sampah [22]. Untuk memenuhi target tersebut tentunya dibutuhkan dana, sehingga perlu dilakukan pengkajian aspek pembiayaan sampah. Faktor pembiayaan di suatu wilayah 
merupakan salah satu faktor utama dalam sistem pengelolaan sampah. Sumber daya penggerak agar roda sistem pengelolaan persampahan di kota lancar adalah aspek pembiayaan [4].

Sumber pembiayaan pengelolaan sampah di Kota Bandung berasal dari iuran jasa pelayanan persampahan masyarakat dan APBD Kota Bandung. Kondisi ideal dalam pembiayaan terhadap pengelolaan sampah adalah $80 \%$ bersumber dari partisipasi masyarakat dan $20 \%$ dari APBD. Namun nyatanya kondisi di lapangan menunjukan nilai yang berbeda, yaitu $80 \%$ berasal dari APBD dan $20 \%$ dari iuran masyarakat [5]. Salah satu bentuk partisipasi masyarakat adalah kesediaan masyarakat dalam membayar atau Willingness to Pay (WTP). Oleh karena itu, WTP masyarakat terhadap tarif jasa layanan sampah perlu dianalisa [6]. Analisa ini dilakukan agar pelayanan pengelolaan sampah semakin baik, maka WTP masyarakat terhadap iuran sampah kota perlu ditingkatkan [7].

Wilayah studi penelitian ini adalah Kecamatan Ujungberung yang berada di Kota Bandung bagian timur. Alasan pemilihan Kecamatan Ujungberung sebagai wilayah studi adalah karena Bandung Timur merupakan wilayah Bandung dengan kontribusi retribusi terendah di Kota Bandung, padahal Bandung Timur merupakan wilayah Bandung dengan luas area terbesar. Kecamatan Ujungberung merupakan salah satu kecamatan di Bandung Timur dengan penduduk terbanyak, sehingga berbanding lurus dengan sampah yang dihasilkan [8]. Realisasi dana yang terkumpul dari Kecamatan Ujungberung untuk tarif jasa layanan (TJL) sampah kota per Tahun 2019 tidak 100\%, melainkan hanya 89\% [9].

Faktor lain penyebab dipilihnya Kecamatan Ujungberung sebagai wilayah studi adalah kondisi TPS nya. Kondisi TPS di Kecamatan Ujungberung tidak semuanya dalam kondisi baik dan belum ada TPS yang menerapkan prinsip 3R [9]. Lalu berdasarkan hasil observasi awal, mayoritas kelurahan di Kecamatan Ujungberung masalah persampahannya adalah penumpukan sampah di TPS yang menyebabkan penumpukan pula di sumber. Pengumpulan sampah dari sumber tidak memenuhi standar pengumpulan yaitu 2 hari sekali, serta tidak adanya upaya pengolahan sampah di TPS. Kecamatan Ujungberung yang batas wilayahnya dibatasi oleh garis merah dapat dilihat pada Gambar 1.

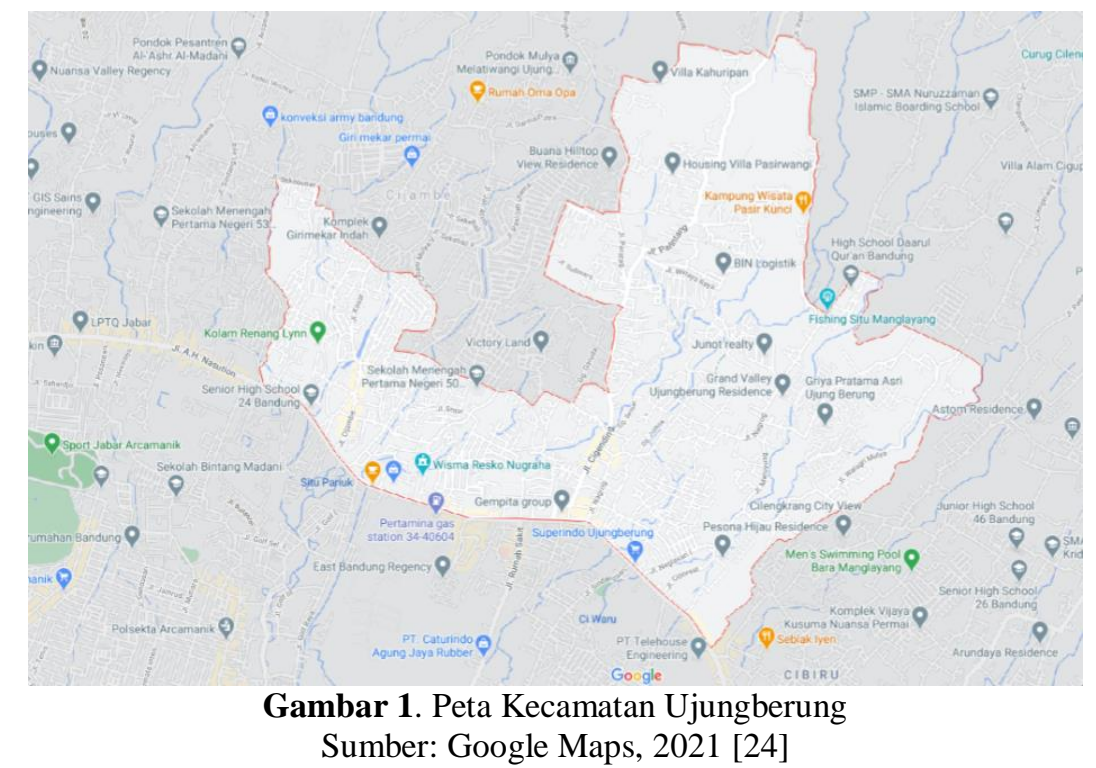

Penelitian ini akan mengkaji aspek pembiayaan dalam pengelolaan persampahan di Kecamatan Ujungberung. Pengkajian berupa menghitung dan menganalisa WTP nya berdasarkan kategori wajib bayar yang dikelompokkan berdasarkan daya listrik yang digunakan masyarakat. Hasil dari pengkajian nantinya akan berkontribusi data untuk DLHK Kota Bandung yang berencana menaikkan tarif jasa layanan sampah kota dan sebagai dasar rekomendasi untuk peningkatan pelayanan persampahan di Kecamatan Ujungberung.

Metode pendekatan yang dipilih adalah metode penilaian kontingen (contingent valuation method: CVM). Teknik dalam CVM yang dipilih adalah teknik payment card, yaitu responden ditawarkan beberapa pilihan nominal TJL, lalu responden hanya diperbolehkan memilih salah satu dari pilihan yang ditawarkan tersebut sesuai keinginan responden. Hasil dari teknik payment card tersebut akan diperoleh tingkat WTP masyarakat. Kelebihan metode ini adalah memberi dorongan yang dapat membantu responden berpikir lebih jelas dan matang mengenai nilai maksimum WTP nya [10]. Pemilihan teknik 
payment card juga didasari karena pada kondisi pandemik Covid-19, sehingga pengumpulan data harus secara daring, dan metode payment card tidak ada proses tawar menawar, sehingga lebih efektif secara daring.

\section{Metode Penelitian}

\section{Metode Pengumpulan Data}

Alat pengumpulan data yang digunakan adalah kuesioner daring. Struktur kuesioner yang disusun mempunyai total 21 (dua puluh satu) pertanyaan yang harus diisi oleh masing-masing responden yang terbagi dalam 3 kelompok pertanyaan. Bagian satu berupa data diri responden sebanyak 8 (delapan) pertanyaan, bagian dua merupakan kondisi eksisting layanan pengelolaan persampahan yang diterima responden sebanyak 10 (sepuluh) pertanyaan, dan bagian tiga merupakan WTP responden sebanyak 3 (tiga) pertanyaan. Sebanyak 9 (sembilan) dari 21 (dua puluh satu) pertanyaan merupakan variabel independen dan 1 pertanyaan merupakan variabel dependen. Kesembilan variabel independen tersebut berangkat dari hipotesa awal sebagai berikut:

- X1: Usia,

Semakin tinggi usia, maka semakin tinggi rasa tanggung jawab mengenai sampah [11].

- X2: Jumlah orang di tempat tinggal

Semakin tinggi jumlah orang di suatu tempat tinggal, maka semakin tinggi pula tanggungannya, sehingga kesediaan membayar kecil [12].

- X3: Tingkat pendidikan

Semkain tinggi tingkat pendidikan masyarakat, maka semakin luas pengetahuan mengenai sampah [13].

- X4: Cara pengumpulan sampah

Jika pengumpulan sampah sudah dilakukan oleh, maka kebersediaan membayarnya akan rendah [14].

- X5: Kuantitas pengumpulan sampah

Semakin sering pengumpulan sampahnya, semakin rendah kebersediaan membayarnya [14].

- X6: Pemilahan sampah

Jika sampah tidak dipilah oleh petugas, maka kebersediaan membayarnya akan tinggi [14].

- X7: Penanggapan keluhan

Semakin ditanggapinya keluhan masyarakat oleh pihak terkait, maka kebersediaan membayarnya cenderung rendah [14].

- X8: Kepuasan

Semakin puas masyarakat akan pelayanan yang diterimanya, maka kebersediaan membayarnya akan semakin rendah [14].

- X9: TJL eksisting

Semkain tinggi TJL eksisting yang dibayarkan memungkinkan masyarakat untuk membayar kenaikan TJL sampah [15][16].

Ke sembilan variabel tersebut merupakan variabel yang bisa mempengaruhi nilai WTP masyarakat [14]. Sedangkan untuk variabel dependennya (Y) adalah kebersediaan masyarakat untuk membayar (WTP) kenaikan TJL sampah kota. Didalam kuesioner tersebut ditampilkan pasar hipotetik berupa visual berbentuk gambar yang berfungsi menggambarkan mengenai kondisi pelayanan sampah eksisting dan yang diharapkan. Pasar hipotetik yang ditampilkan adalah:

- Kondisi TPS di Kecamatan Ujungberung

- Luas TPS yang diharapkan

- Fasilitas TPS yang diharapkan, seperti bidogester, mesin press, tangka septik, menara air, keranjang Takakura, gerobak sorong, dan mesin pencacah

- Kegiatan warga mengenai lingkungan yang diharapkan

Visualisasi pasar hipotetik yang ditampilkan dapat dilihat pada Gambar 2 hingga Gambar 7. Untuk pengambilan data responden menggunakan probability sampling, yaitu disproportionate stratified random sampling sesuai kelas pelanggan, karena jumlah tiap kelas tidak proporsional. Penentuan jumlah sampel yang digunakan adalah dengan cara Cross Section seperti pada Persamaan 1 [17]. 


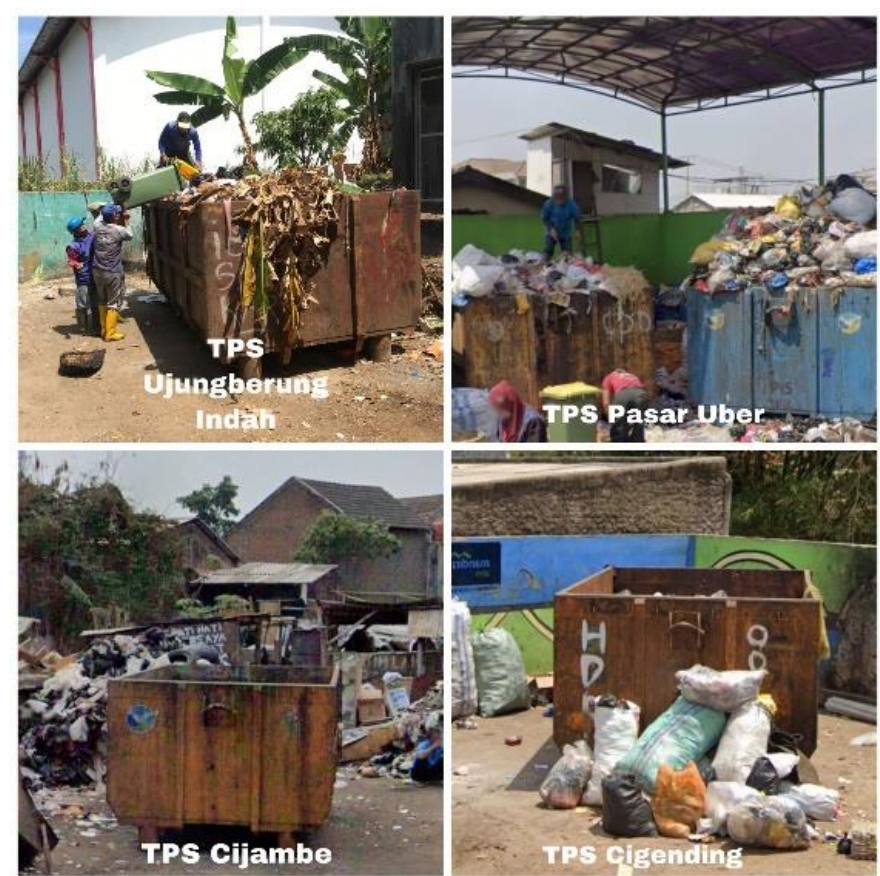

Gambar 2. Kondisi TPS di Kecamatan Ujungberung Sumber: Hasil observasi, 2020.
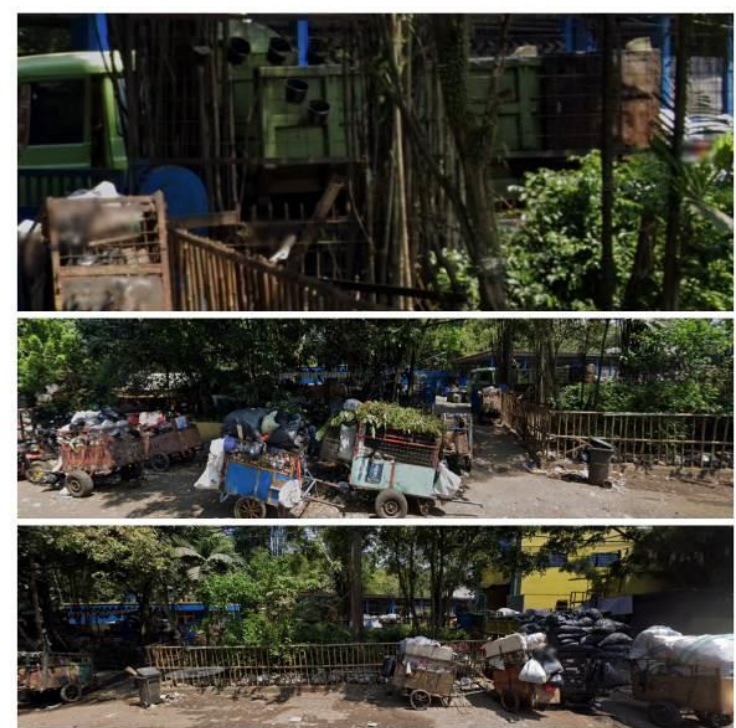

Gambar 3. Luas TPS yang diharapkan $\left(>200 \mathrm{~m}^{2}\right)$ Sumber: Hasil observasi, 2020
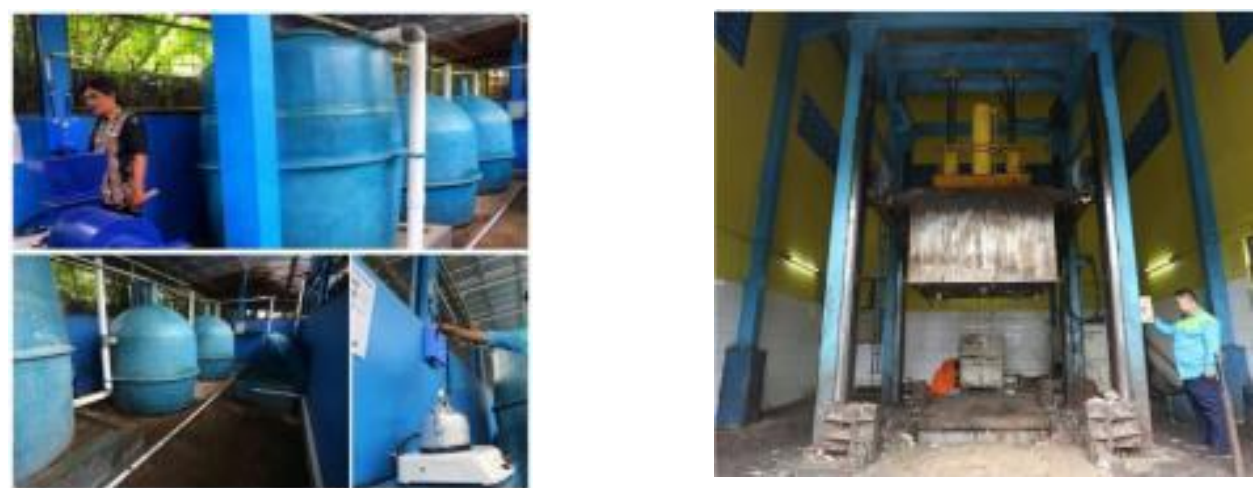

Gambar 4. Alat pengolah sampah berupa biodigester (kiri) dan mesin press (kanan) Sumber: Hasil observasi, 2020. 

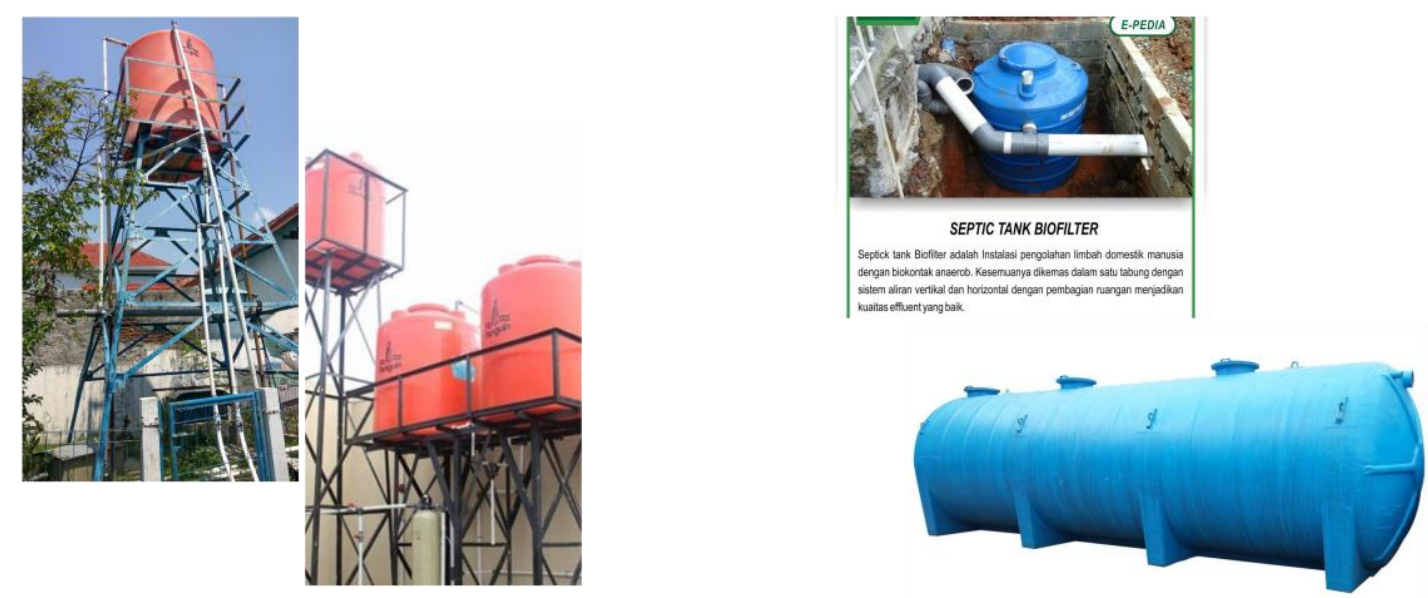

Gambar 5. Bangunan pendukung berupa menara air (kiri) dan tangki septik (kanan) Sumber: Hasil observasi, 2020.

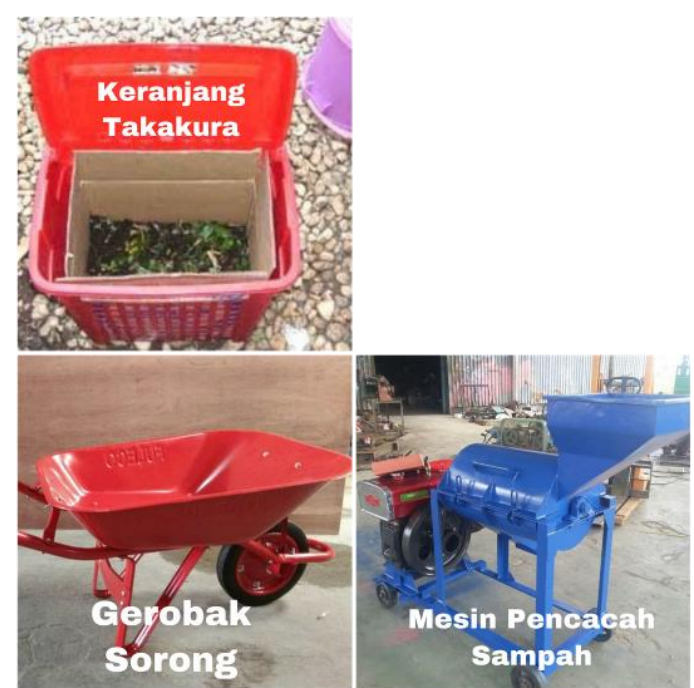

Gambar 6. Fasilitas alat tambah di TPS yang diharapkan Sumber: Hasil observasi, 2020.

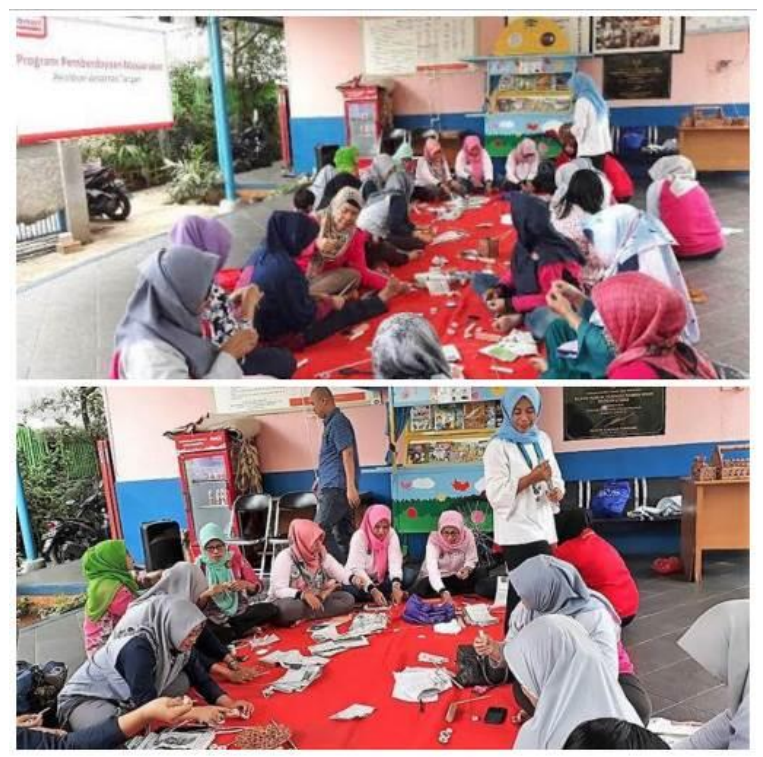

Gambar 7. Kegiatan lingkungan yang diharapkan untuk warga Sumber: Hasil observasi, 2020. 


$$
\mathrm{n}=\frac{\left(\mathrm{Z}^{2} 1-\frac{\alpha}{2}\right) \mathrm{p} \mathrm{q} \mathrm{N}}{\mathrm{d}^{2}(\mathrm{~N}-1)+\left(\mathrm{Z}^{2} 1-\frac{\alpha}{2}\right) \mathrm{p} \mathrm{q}}
$$

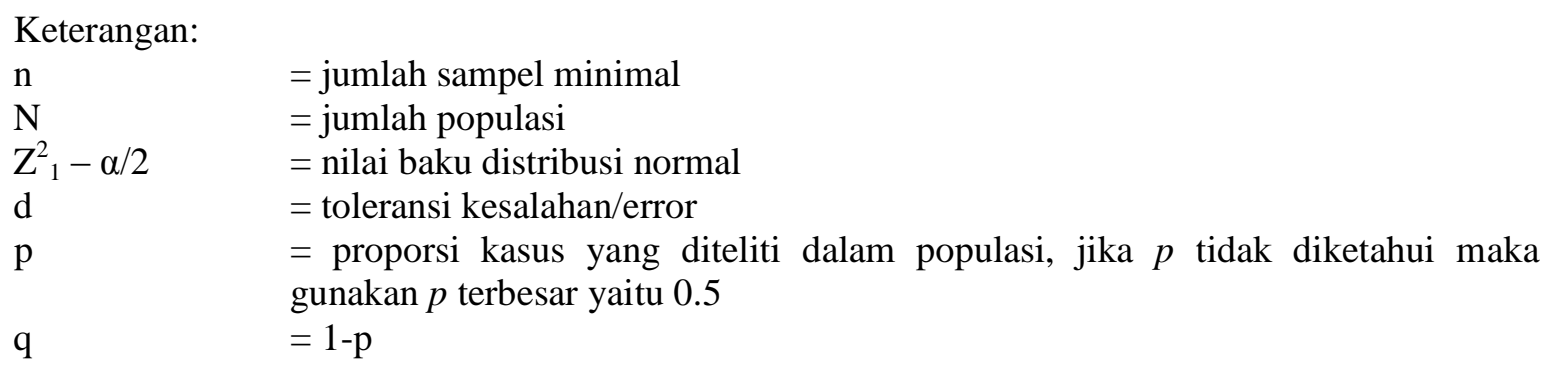

Besar nilai $Z_{1}^{2}-\alpha / 2$ dapat dilihat pada Tabel 1.

Tabel 1. Nilai baku distribusi normal

\begin{tabular}{cc}
\hline$\alpha$ & $\mathrm{Z}^{2}{ }_{1}-\alpha / 2$ \\
\hline $1 \%$ & 2.58 \\
$5 \%$ & 1.96 \\
$10 \%$ & 1.64 \\
\hline
\end{tabular}

Sumber: Juanda, 2014 [17]

Sesuai data Badan Pusat Statistik (BPS) Kota Bandung, jumlah kepala keluarga (KK) di Kecamatan Ujungberung sebanyak 4125 KK [25]. Dengan tingkat kesalahan yang dipilih adalah $10 \%$, melalui Persamaan 1, didapat jumlah minimum sampelnya adalah 66 sampel. Penyebaran kuesioner menggunakan formulir Google dan pengisian dilakukan secara daring. Penentuan kelas ditentukan dari tiap kategori wajib bayar yang dikelompokkan berdasarkan daya listrik yang digunakan seperti pada Tabel 2.

Tabel 2. Golongan wajib bayar TJL kota

\begin{tabular}{ccc}
\hline No & Golongan & Daya Listrik \\
\hline 1 & Kelas 1 & $450-900 \mathrm{VA}$ \\
2 & Kelas 2 & $900-1300 \mathrm{VA}$ \\
3 & Kelas 3 & $1300-2200 \mathrm{VA}$ \\
4 & Kelas 4 & $2200-3600 \mathrm{VA}$ \\
5 & Kelas 5 & $3600-6600 \mathrm{VA}$ \\
\hline 6 & Kelas 6 & $>6600 \mathrm{VA}$ \\
\hline \multicolumn{2}{l}{ Sumber: Perwal Kota Bandung No.316 Tahun 2013 [18]. }
\end{tabular}

\section{Metode Analisa Data}

Tahapan analisa data yang pertama adalah menganalisa kondisi eksisting pelayanan sesuai hasil kuesioner, lalu dianalisa persepsi masyarakat mengenai pelayanan sampah, selanjutnya melakuan analisa regresi linear. Analisa regresi linear yang digunakan adalah analisa regresi linear berganda, karena variabel independennya (X) lebih dari 2 (dua). Analisa ini bertujuan untuk mengetahui keberpengaruhan kesembilan variable X terhadap WTP. Pada analisa regresi linear berganda ini perlu dilakukan serangkaian uji awal terelebih dahulu, yaitu uji normalitas, uji linearitas, uji multikolinearitas, dan uji heteroskedastisitas. Selanjutnya, dianalisa hubungan antara variabel independen dengan variabel dependennya baik secara parsial maupun secara simultan, lalu dibuat persamaan regresi linearnya berdasarkan hasil analisa regresi linear bergandanya.

$$
\mathrm{Y}=\mathrm{B}(\text { constant })+\sum \mathrm{B} \text { Variabel } \mathrm{X}
$$

\section{Keterangan:}

$\mathrm{B}=$ Nilai pengaruh besarnya perubahan

$\mathrm{X} \quad=$ Variabel Independen

$\mathrm{Y} \quad=$ Variabel Dependen 
Selanjutnya, dihitung nilai WTP rata-rata (EWTP) dan nilai WTP totalnya (TWTP) untuk mengetahui tarif jasa layanan sampah kota yang optimum untuk Kecamatan Ujungberung.

Berikut persamaan dalam menghitung EWTP [19].

$$
\mathrm{EWTP}=\mathrm{WTP} \times \frac{\text { Responden WTP }}{\text { Responden Total }}
$$

TWTP = Nilai WTP total Keterangan:

EWTP $\quad$ = Nilai WTP rata-rata

WTP $\quad$ = Besaran WTP responden

Responden WTP = Responden yang memilih WTP tersebut

Responden Total = Responden keseluruhan

Berikut persamaan dalam menghitung TWTP [19].

$$
\text { TWTP }=\text { WTP x Jumlah KK. }
$$

Keterangan:

WTP = Besaran WTP responden

KK = Kepala Keluarga

Rekomendasi peningkatan pelayanan pengelolaan sampah yang paling optimal untuk diterapkan di Kecamatan Ujungberung bisa ditentukan setelah mendapatkan persamaan regresi linear berganda dan besaran EWTP dan TWTP.

\section{Hasil dan Pembahasan}

\section{Kondisi Eksisting}

Gambar 8 dan Gambar 9 menunjukkan kondisi eksisting persentase cara pengumpulan sampah dan persentase kuantitas pengumpulan sampah di Kecamatan Ujungberung. Sebanyak 94\% masyarakat sampahnya dikumpulkan oleh petugas untuk dibawa ke TPS, 5\% dibuang sendiri, dan 1\% sisanya dibakar/ ditimbun. Persentase sampah yang dibawa petugas menunjukan bahwa setidaknya $94 \%$ masyarakat mempunyai kewajiban untuk membayar tarif jasa layanan (TJL) sampah tingkat kota. Namun, kondisi eksisting di Kecamatan Ujungberung menunjukkan hanya sebesar 89\% masyarakat yang membayar TJL sampah tingkat kota (dari seharusnya 94\%) [9].

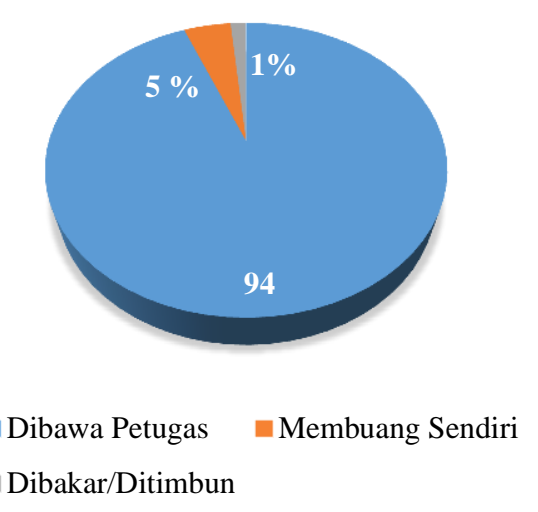

Gambar 8. Cara pengumpulan sampah Sumber: Hasil analisa, 2020 


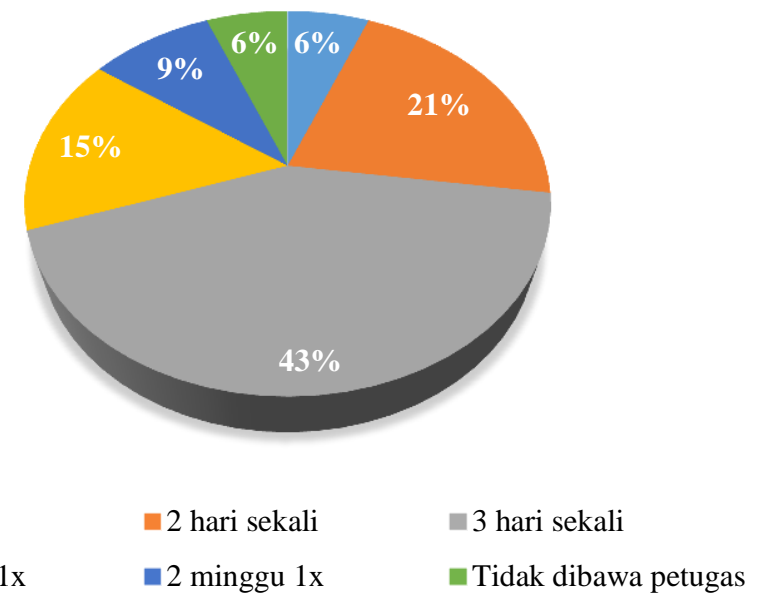

Gambar 9. Kuantitas pengumpulan sampah Sumber: Hasil analisa, 2020

Mayoritas kuantitas pengumpulan sampah (43\%) di Kecamatan Ujungberung adalah 3 hari sekali yang mana menunjukkan bahwa mayoritas pengumpulan masih belum memenuhi standar kuantitas pengumpulan yang diatur dalam Peraturan Menteri Pekerjaan Umum RI No. 3 Tahun 2013 Tentang Penyelenggaraan Prasarana dan Sarana Persampahan Dalam Penanganan Sampah Rumah Tangga Dan Sampah Sejenis Sampah Rumah Tangga yaitu 2 hari sekali [23]. Hal tersebut yang membuat sebagian masyarakat mengeluh akan penumpukan sampah di sumber (rumah masyarakat).

Pada Gambar 10 menunjukkan kondisi pemilahan sampah di Kecamatan Ujungberung, mayoritasnya (61\%) adalah warga dan petugas sama-sama tidak memilah sampah. Hal tersebut terjadi karena petugas tidak diberi sumber daya dan fasilitas untuk memilah sampah, sehingga wargapun tidak memilah.

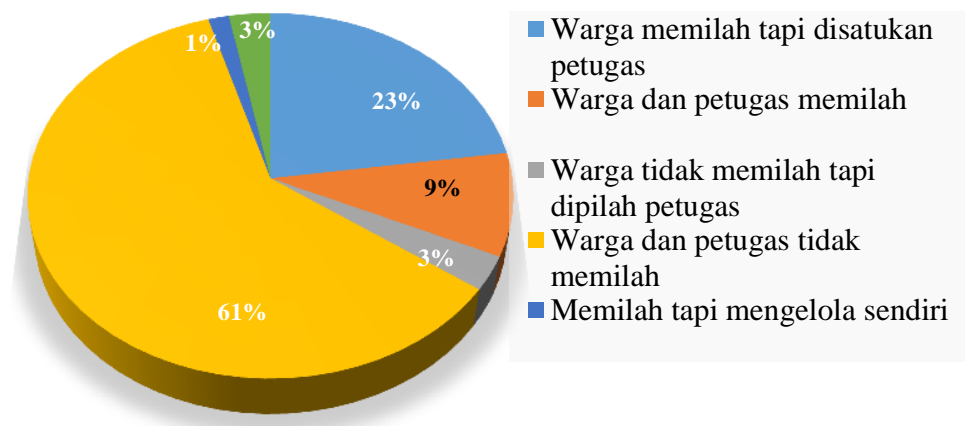

Gambar 10. Kondisi pemilahan sampah

Sumber: Hasil analisa, 2020

Namun dapat dilihat juga bahwa sebesar 23\% masyarakat tetap memilah sampah walau pada akhirnya disatukan kembali oleh petugas saat pengumpulan. Hal tersebut menjadi tanda bahwa masyarakat Kecamatan Ujungberung sudah mempunyai modal dasar untuk memilah sampah jika dikelola dengan baik.

\section{Analisa Persepsi Masyarakat}

Pada Gambar 11 menunjukkan persentase penanggapan keluhan masyarakat oleh pihak terkait (kiri) dan persentase kepuasan masyarakat akan pelayanan yang diterima (kanan). Besarnya persentase masyarakat yang sama sekali tidak mengajukan keluhan (62\%) berbanding lurus dengan besarnya persentase masyarakat yang puas dengan pelayanan sampah yang diterima (78\%). Hal tersebut dapat terjadi karena saat masyarakat sudah puas terhadap layanan yang diterima, maka tidak akan muncul keluhan terhadap layanan tersebut. 

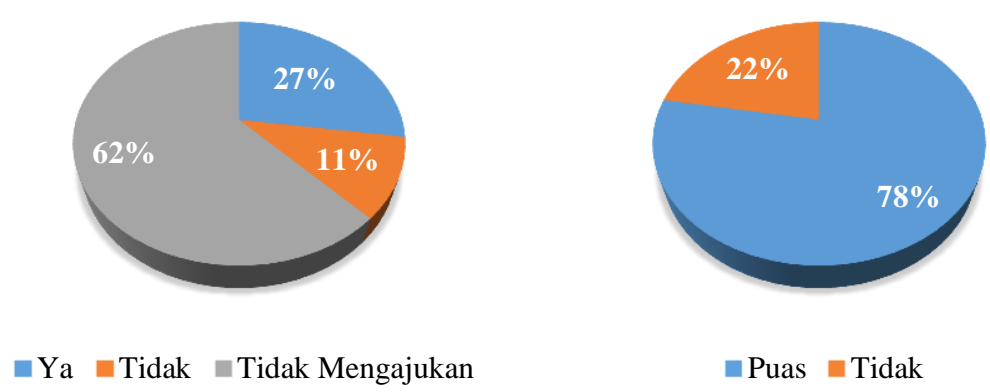

Gambar 11. Persepsi masyarakat

Sumber: Hasil analisa, 2020

Walaupun sudah puas dengan layanan eksisting, persentase WTP masyarakat terhadap kenaikan TJL cukup besar, yakni 88\% seperti pada Gambar 12.

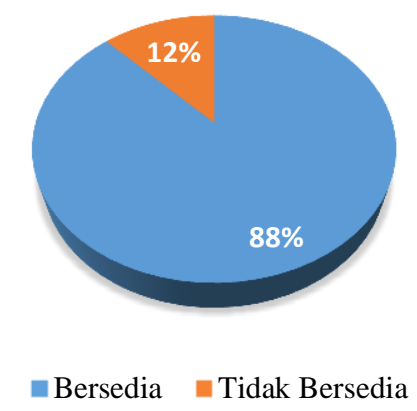

Gambar 12. WTP masyarakat

Sumber: Hasil analisa, 2020

Mayoritas alasan kesediaan masyarakat adalah masyarakat merasa saat pengelolaan sampah yang baik akan berdampak baik pula ke lingkungan. Dampak positif tersebut akan terasa juga oleh masyarakat. Sedangkan masyarakat yang tidak bersedia, mayoritas beralasan bahwa TJL kota bukan merupakan tanggung jawab masyarakat, melainkan tanggung jawab pemerintah.

\section{Analisa Regresi Linear Berganda}

Setelah memenuhi persyaratan pada uji normalitas, linearitas, multikolinearitas, dan heterokedastisitas, maka dapat dilakukan analisa regresi untuk mengetahui keberpengaruhan antar variabel. Berikut output analisa regresi linear berganda untuk uji F seperti pada Tabel 3.

Tabel 3. Nilai R dan F

\begin{tabular}{ccccc}
\hline $\mathrm{R}$ & R square & F hitung & F tabel & Sig \\
\hline 0,638 & 0,407 & 4,266 & 2,05 & 0 \\
\hline \multicolumn{5}{c}{ Sumber: Hasil analisa, 2020}
\end{tabular}

Karena nilai $\mathrm{F}$ hitung $>\mathrm{F}$ tabel, maka kesembilan variabel independen mempunyai pengaruh secara simultan terhadap WTP sebesar 40.7\% (Rsquare) [20]. Sedangkan secara parsial, pengaruh masingmasing variabel independen terhadap WTP terdapat pada Tabel 4.

Tabel 4. Nilai t

\begin{tabular}{|c|c|c|c|c|}
\hline Variabel & Residuals & $\mathrm{t}$ hitung & Sig & $\mathrm{t}$ tabel \\
\hline $\mathrm{X} 1$ & \multirow{5}{*}{56} & $-3,582$ & 0,001 & \multirow{5}{*}{2,00324} \\
\hline $\mathrm{X} 2$ & & $-1,866$ & 0,074 & \\
\hline X3 & & $-0,656$ & 0,796 & \\
\hline $\mathrm{X} 4$ & & 1,605 & 0,214 & \\
\hline $\mathrm{X} 5$ & & 0,268 & 0,549 & \\
\hline
\end{tabular}




\begin{tabular}{|c|c|c|c|c|}
\hline Variabel & Residuals & t hitung & Sig & t tabel \\
\hline X6 & & $-1,249$ & 0,229 & \\
\hline $\mathrm{X} 7$ & & 1,246 & 0,234 & \\
\hline $\mathrm{X} 8$ & & 1,203 & 0,105 & \\
\hline X9 & & $-2,824$ & 0,007 & \\
\hline
\end{tabular}

Yang nilai t hitung > t tabel hanya variabel X1 (usia) dan X9 (TJL Eksisting), artinya adalah hanya usia dan TJL eksistinglah yang mempunyai pengaruh signifikan terhadap WTP [20]. Nilai kontribusi besarnya perubahan (B) seperti pada Tabel 5 untuk diinput pada persamaan regresi linear berganda.

Tabel 5. Nilai B

\begin{tabular}{cccc}
\hline Variabel & B & Variabel & B \\
\hline Constant & 2,65 & & \\
X1 & $-0,062$ & X6 & $-0,134$ \\
X2 & $-0,089$ & X7 & 0,083 \\
X3 & $-0,04$ & X8 & 0,114 \\
X4 & 0,156 & X9 & $-0,083$ \\
X5 & 0,009 & X6 & $-0,134$ \\
\hline
\end{tabular}

Sumber: Hasil Analisa, 2020

Dengan menggunakan Persamaan 2, didapat lah persamaan regresi linear bergandanya sebagai berikut:

$$
\begin{gathered}
\mathrm{WTP}=\mathrm{B}(\text { constant })+\mathrm{B}(\text { Usia })+\mathrm{B}(\mathrm{TJL}) \\
\mathrm{WTP}=2,65+(-0,062) \text { Usia }+(-0,083) \mathrm{TJL} \\
\mathrm{WTP}=2,65-0,062 \text { Usia }-0,083 \mathrm{TJL}
\end{gathered}
$$

Berdasarkan persamaan regresi linear berganda diatas, dapat di interpretasikan sebagai berikut:

- Nilai konstanta sebesar 2,65 menunjukkan bahwa jika variabel X (dalam hal ini variabel usia dan TJL) bernilai konstan, maka nilai WTP nya sebesar nilai konstanta, yaitu 2,65.

- Koefisien regresi variabel usia bernilai -0,062 menunjukkan bahwa jika variabel X lain bernilai konstan dan variabel ini mengalami kenaikan satu satuan, maka nilai WTP akan mengalami penurunan sebesar 0,064. Itu karena koefisien bernilai negatif yang artinya hubungan antara variabel usia dengan WTP adalah negatif, yaitu semakin muda usia masyarakat, maka nilai WTP akan semakin tinggi, begitupun sebaliknya.

- Koefisien regresi variabel TJL bernilai -0,083 menunjukkan bahwa jika variabel X lain bernilai konstan dan variabel ini mengalami kenaikan satu satuan, maka nilai WTP akan mengalami penurunan sebesar 0,083. Itu karena koefisien bernilai negatif yang artinya hubungan antara variabel usia dengan WTP adalah negatif, yaitu semakin tinggi TJL yang dibayarkan masyarakat, maka nilai WTP akan semakin kecil, begitupun sebaliknya.

\section{Analisa Besaran WTP}

1. WTP Rata-Rata (EWTP)

Untuk nilai EWTP keseluruhan, dengan menggunakan Persamaan 3, maka didapat distribusi besaran EWTP nya dapat dilihat pada Tabel 6.

Tabel 6. Distribusi besaran EWTP

\begin{tabular}{cccc}
\hline $\begin{array}{c}\text { WTP Keseluruhan } \\
(\mathrm{Rp})\end{array}$ & $\begin{array}{c}\text { Jumlah } \\
\text { Responden } \\
(\text { Jiwa })\end{array}$ & $\begin{array}{c}\text { Frekuensi } \\
\text { Relatif (Pfi) }\end{array}$ & $\begin{array}{c}\text { EWTP } \\
(\mathrm{Rp})\end{array}$ \\
\hline 10.000 & 6 & 0.09 & 909 \\
15.000 & 7 & 0.11 & 1.591 \\
20.000 & 11 & 0.17 & 3.333 \\
25.000 & 5 & 0.08 & 1.894 \\
30.000 & 16 & 0.24 & 7.273 \\
50.000 & 16 & 0.24 & 12.121 \\
55.000 & 5 & 0.08 & 4.167 \\
Total & 66 & 1 & 31.288 \\
\hline \multicolumn{4}{c}{ Sumber: Hasil perhitungan, 2020 } \\
\hline
\end{tabular}


Nominal sebesar Rp 31.288 tersebut merupakan dana yang bisa dijadikan acuan untuk menaikkan TJL demi kepentingan peningkatan pelayanan SPS di Kecamatan Ujungberung.

2. Surplus Konsumen

Surplus konsumen adalah kelebihan atau perbedaan antara kepuasan total atau total utility (yang dinilai dengan uang) yang dinikmati konsumen dari mengonsumsi sejumlah barang tertentu dengan pengorbanan totalnya (yang dinilai dengan uang), untuk memperoleh atau mengonsumsi jumlah barang tersebut [21]. Berikut persamaannya:

$$
\begin{array}{ll}
\multicolumn{3}{c}{\text { Surplus Konsumen }=\overline{\mathrm{x}} \text { Harga Optimalisasi }-\overline{\mathrm{x}} \text { Harga Pasar......................(1) }} \\
\begin{array}{ll}
\text { Ket: } & \text { : rata-rata TJL yang bersedia masyarakat bayar untuk peningkatan } \\
\overline{\mathrm{x}} \text { Harga Optimalisasi } & \text { pelayanan pengelolaan sampah di Kecamatan Ujungberung }
\end{array} \\
\overline{\mathrm{x}} \text { Harga Pasar } & \text { : rata-rata TJL eksisting }
\end{array}
$$
berikut:

Dengan menggunakan Persamaan 5, maka didapat nilai surplus konsumennya adalah sebagai

$$
\begin{gathered}
\text { Surplus Konsumen }=\text { EWTP Keseluruhan }-\bar{x} \text { TJL Eksisting } \\
\text { Surplus Konsumen }=\operatorname{Rp~} 31.288-\operatorname{Rp} 6.545 \\
\text { Surplus Konsumen }=\operatorname{Rp} 24.743
\end{gathered}
$$

Nilai surplus konsumen tersebut menunjukkan bahwa ada peningkatan nominal untuk TJL sebesar Rp 24.743 per responden dari TJL eksisting, yang mana dana tersebut bisa digunakan untuk peningkatan pelayanan SPS di Kecamatan Ujungberung.

3. WTP Total (TWTP)

Dari 4.125 KK di Kecamatan Ujungberung, tidak semuanya bersedia membayar kenaikan TJL. Persentase yang bersedia untuk membayar kenaikan TJL adalah $88 \%$, sehingga jumlah KK yang bersedia membayar adalah:

$$
\begin{gathered}
\text { Jumlah KK bersedia }=\text { Jumlah KK total } \times \text { \%ersedia } \\
\text { Jumlah KK bersedia }=4.125 \times 0.88 \\
\text { Jumlah KK bersedia }=3.630 \mathrm{KK}
\end{gathered}
$$

Berikut distribusi nilai TWTP dari setiap nilai WTP terdapat pada Tabel 7.

Tabel 7. Distribusi besaran TWTP

\begin{tabular}{ccccc}
\hline $\begin{array}{c}\text { WTP Keseluruhan } \\
(\mathrm{Rp})\end{array}$ & $\begin{array}{c}\text { Jumlah } \\
\text { Responden } \\
\text { (Jiwa) }\end{array}$ & Pfi & Jumlah KK & TWTP(Rp) \\
\hline 10.000 & 6 & 0.09 & 330 & 3.300 .000 \\
15.000 & 7 & 0.11 & 385 & 5.775 .000 \\
20.000 & 11 & 0.17 & 605 & 12.100 .000 \\
25.000 & 5 & 0.08 & 275 & 6.875 .000 \\
30.000 & 16 & 0.24 & 880 & 26.400 .000 \\
50.000 & 16 & 0.24 & 880 & 44.000 .000 \\
55.000 & 5 & 0.08 & 275 & 15.125 .000 \\
Total & 66 & 1 & 3630 & 113.575 .000 \\
\hline \multicolumn{5}{c}{}
\end{tabular}

Sumber: Hasil perhitungan, 2020.

Berdasarkan Tabel 7, nilai TWTP di Kecamatan Ujungberung adalah sebesar Rp 113.575.000. Nominal dana tersebut merupakan acuan untuk rekomendasi terhadap upaya optimasi pelayanan pengelolaan sampah di Kecamatan Ujungberung. 


\section{Kesimpulan}

Berdasarkan hasil perhitungan dan analisa, dapat disimpulkan bahwa masyarakat Kecamatan Ujungberung yang bersedia membayar kenaikan TJL adalah sebesar $88 \%$, sisanya sebesar $12 \%$ tidak bersedia. Selanjutnya, dari kesembilan variabel independen yang diteliti, secara simultan mempunyai pengaruh sebesar $40.7 \%$ terhadap kebersediaan masyarakat Kecamatan Ujungberung untuk membayar kenaikan TJL (variabel Y), namun hanya variabel usia dan variabel TJL yang mempunyai pengaruh signifikan secara parsial. Berdasarkan hasil persamaan regresi linear berganda yang didapat, hubungan antara variabel usia dan variabel TJL dengan kebersediaan masyarakat Kecamatan Ujungberung untuk membayar kenaikan TJL adalah negatif, yaitu semakin tinggi tingkat usia masyarakat maka WTP akan semakin rendah, begitupun sebaliknya. Untuk TJL, semakin kecil TJL yang dibayarkan masyarakat, maka WTP nya akan semakin besar, begitupun sebaliknya. Untuk besaran nilai WTP, WTP rata-rata Kecamatan Ujungberung adalah Rp 31.288, sedangkan nilai WTP totalnya adalah Rp 113.575.000

\section{Referensi}

[1] Badan Standarisasi Nasional 1991, Tata Cara Teknik Operasional Pengelolaan Sampah Perkotaan (Vol. 12-03), Jakarta: Badan Standarisasi Nasional.

[2] Badan Standarisasi Nasional 2002, Tata Cara Teknik Operasional Pengelolaan Sampah Perkotaan (Vol. 19-2454), Jakarta: Badan Standarisasi Nasional.

[3] Badan Standarisasi Nasional 1990. Tata Cara Teknik Operasional Pengelolaan Sampah Perkotaan (Vol. T-13), Jakarta.

[4] E. Damanhuri, T. Padmi, Diktat Kuliah Pengelolaan Sampah. Program Studi Teknik Lingkungan, Fakultas Teknik Sipil dan Lingkungan, Institut Teknologi Bandung, 2010, Google Maps. 2021. Peta Kecamatan Ujungberung.

[5] Bappeda Kota Bandung 2014, Kajian Penyesuaian Retribusi Sampah dan Manajemen Pengelolaan Sampah di Kota Bandung, Bandung.

[6] R. Zakaria, "Analisis Kemauan Membayar Masyarakat Untuk Peningkatan Kualitas Pengelolaan Sampah di Kota Makassar Menggunakan CVM. (Magister)," Institut Teknologi Bandung, 2013.

[7] E. Hartono, "Analisa Willingness To Pay dalam Upaya Peningkatan Pelayanan Pengelolaan Sampah di Kota Brebes Melalui Peningkatan Kemampuan Pembiayaan,” Universitas Diponegoro, Semarang, 2006.

[8] PD Kebersihan Kota Bandung, Laporan Kinerja Tahun 2013, Bandung, 2013.

[9] PD Kebersihan Kota Bandung, Laporan Kinerja Tahun 2019, Bandung, 2020.

[10] Dhaniswara, M, "Analisis WTP Menuju Pelestarian Ekosistem Wisata Bahari Karimunjawa, Jawa Tengah," Fakultas Ekonomi dan Bisnis, Universitas Diponegoro, 2014.

[11] S. Adam, M. Shamsudin, S. Sidique, K. Rahim, A. Radam, "Attribute Prioritization in Choice Experiment Pre-Design: Suggested Method and Application to Solid Waste Management Service Improvement," J. of Energy Technologies and Policy, 2013.

[12] D. Indramawan, I. Susilowati, "Analisis Willingness to Pay Pengelolaan Sampah Terpadu di Kecamatan Semarang Barat Kota Semarang," Fakultas Ekonomi dan Bisnis, 2014.

[13] D. Awunyo-Vitor, "Urban Households Willingness to Pay for Improved Solid Waste Disposal Services in Kumasi Metropolis," Urban Studies Research, Ghana, 2013.

[14] N. Jaya, "Faktor-Faktor Yang Mempengaruhi Penerimaan Retribusi Sampah Di Kabupaten Badung," Universitas Udayana, Bali, 2014.

[15] M. Yunis, "Analisis Tingkat Kesediaan Membayar Masyarakat Terhadap Kebersihan du Kecamatan Tampan Pekanbaru," Universitas Negeri Riau, 2010.

[16] I. Susanto, B. Rahardyan, "Analisis Penerimaan Retribusi Sampah Masyarakat dalam Upaya Peningkatan Pelayanan Pengelolaan Persampahan di Kota Bandung Bagian Timur," Institut Teknologi Bandung, 2016.

[17] Juanda, Juwita, "Perbandingan Algoritme Naïve Bayes Dan Apriori Dalam Sistem Rekomendasi Pemilihan Warna Cat Dinding Kamar Tidur Berdasarkan Kepribadian," Universitas Pendidikan Indonesia, 2014.

[18] Walikota Bandung, Rancangan Peraturan Walikota Bandung tentang Tarif Jasa Layanan Sampah, DLHK, Bandung, 2020.

[19] H. Astri, "Analisis Kesediaan Membayar (Willingness To Pay) Dan Kesediaan Untuk Menerima Kompensasi (Willingness To Accept) Dari Keberadaan Tempat Penampungan Sementara Ciwastra Dengan Contingent Valuation Method," Universitas Pasundan, Bandung, 2018. 
[20] C. Junaidi, "Membaca dan Menggunakan Tabel Distribusi t dan F," Fakultas Ekonomi dan Bisnis, Universitas Jambi, 2014.

[21] Samuelson dan Nordhaus, Ilmu Makroenomi, McGraw-Hill, Media Global Edukasi, 2003.

[22] Presiden Indonesia, "Peraturan Presiden Nomor 97 Tahun 2017 Tentang Kebijakan dan Strategi Nasional Pengelolaan Sampah Rumah Tangga dan Sampah Sejenis Sampah Rumah Tangga," Sekretariat Negara, Jakarta, 2017.

[23] Menteri PUPR, "Peraturan Menteri Pekerjaan Umum RI No.3 Tahun 2013 Tentang Penyelenggaraan Prasarana dan Sarana Persampahan Dalam Penanganan Sampah Rumah Tangga Dan Sampah Sejenis Sampah Rumah Tangga," Jakarta, 2013.

[24] Google Maps, "Peta Kecamatan Ujungberung," https://www.google.com/maps/place/Ujung+Berung,+Bandung+City,+West+Java/@ 6.9049625,107.6870828,14z/data=!3m1!4b1!4m5!3m4!1s0x2e68dd22b4875447:0x5f6466543fd706c 4!8m2!3d-6.9064866!4d107.7073688, 2 Januari 2021

[25] Badan Pusat Statistik Jawa Barat, “Kecamatan Ujungberung Dalam Angka 2019," Bandung, 2019. 